\title{
The Implementation of Social Media to DevelopStudents' Writing Skill on Digital Marketing
}

\author{
Muhammad Natsir ${ }^{1}$, Rita Suswati ${ }^{2}$, Sisila Fitriany Damanik ${ }^{3}$, Isli Iriani Indiah Pane ${ }^{4}$, Fauziah \\ Khairani Lubis ${ }^{5}$ \\ 1,2,3,4,5 Faculty of Languages and Arts, Universitas Negeri Medan, Indonesia
}

\begin{tabular}{|c|c|}
\hline ARTICLE INFO & ABSTRACT \\
\hline Article history: & \multirow{14}{*}{$\begin{array}{l}\text { Digital marketing has become a new way to exchange things, starting } \\
\text { from information to selling things. UniversitasNegeri Medan } \\
\text { (UNIMED) as one of the educational university tries to engage to this } \\
\text { digital world. Since the currentfacility of multimedia laboratorybased } \\
\text { on Computer Assisted Language learning (CALL), the } \\
\text { implementation of e-learning has been developed. Through English } \\
\text { for Spesific Purposes (ESP), the students learn further on e-world. } \\
\text { The aim of this research is to find out the students' ability in writing } \\
\text { an advertisement using social media. This research used a } \\
\text { development research approach (R \& D) that adopts a model } \\
\text { developed by Borg \& Gall and the questionnares were analyzed by } \\
\text { Linkert Scale formula. The research activities wasin the second } \\
\text { semester consist of } 30 \text { english literature students carried out pre- and } \\
\text { post-test, expert validation, and final product. The result shown: 1) } \\
\text { social media like Instagram can be developed as the writing material; } \\
\text { 2) students' ability in writing using social media can be implemented } \\
\text { in e-marketing to design an advertisement. Furthermore, it's } \\
\text { suggested to do more research on digital marketing to offer a wider } \\
\text { opportunies to students in deciding the best job in the future. }\end{array}$} \\
\hline Received Sep 28, 2018 & \\
\hline Revised Jan 02, 2018 & \\
\hline & \\
\hline Keywords: & \\
\hline Social Media, & \\
\hline Writing Skill, & \\
\hline Digital Marketing & \\
\hline & \\
\hline & \\
\hline Clonflict of Interest: & \\
\hline None & \\
\hline Funding: & \\
\hline & \\
\hline
\end{tabular}

Corresponding Author: Muhammad Natsir, Faculty of Languages and Arts, Universitas Negeri Medan, Jl. Willem Iskandar Pasar V-Kotak Pos No. 1589 - Medan 20221 Indonesia. Tel: +6281260990104. E-Mail: mnatsir0@gmail.com

Copyright (C) Association of Language Teachers in Southeast Asia. All rights reserved

\section{INTRODUCTION}

English Literature program of UNIMED prepare the students to be ready in the digital world. Through ESP, students learn how to be other profession than teachers. They study how to be a banker, a secretary, reporter, and others in the field work practice (PKL). The latest program of ESP is the online marketing. Literature students have been tought how to design an advertisement in e-marketing in order to be part of the bussiness world, so they don't have to come to work places, worried about the working hours. They can be the one who design or even sell anything by learning how to write the advertisement in the on line marketing. The current option is to get bigger opportunity to achieve massive income after graduating.

This activity is one of the solutions in facing the industrial revolution by building the right scaffolding to these learners as President Jokowi stated in a seminar "The Future of Global Higher Education" at Batavia Tower Jakarta (CNN Indonesia.com. retrieved Dec 08, 2018). Welcoming the industrial revolution of 4. 0, The Indonesia Pesident, Joko Widodo, initiate and launch the program called " Making Indonesia 4.0", The goverment commit to embrace the industrial 
revolution future, so the educational system should be reformed and repared. Teachers should able to design the materials, method andaccomodate themselves with technology. The word KKN (Corruption, Collution and Nepotism) had been reformed into (Communication, Collaboration and Networking).

To own the e-marketing, the learners should understand some factors that make one advertisement well recognized. First, social media, according to King and Sen, 2013; many aspects of human lives affected by the social activities, so there's no wonder that it can be also applied to education and learning. The integration of social media may open a new thing to engage the teaching and learning process. (Zepke and Leach, 2010). Social media that most frequently used by the literature students of UNIMED is Instagram (Ig), Facebook (FB) and Whatsapps (WA). They used FB to announce anything that related to their topic in class, WA is an application to discuss and chat of a material and the content of Ig is the example and material to write. So, learners can study how to design an advertisement via Ig.

Further, branding. Alvarez and Fournier, 2016; Kumar and Gupta, 2016; Lamberton and Stephen, 2016 stated one of the most important thing in marketing to connect with the customers on digital world is branding. Various brands that offered to the users of social media affect the competition in digital platform, which becomes a good way for English literature students program of UNIMED to learn. They can see which product has a better brand that attract the students to purchare it. Students can learn the factors that cause social media users interest in checking certain product whether the price and tagline has intimate connection with the users, and easy access to buy or others.

Last is content. Students need to learn how to create an attractive,eye catching and colourful product with the choosen phrase to highlight the advantages of a brand. Students are not only expected to write a word but also they have to understand the marketing need. What the customers expect, the customers level etc. Their ability in writing the advertisement will be influenced by some psychological situations, from in and outside the students; competences, knowledge, method also part of them.

From the preliminary data, it's shown that students' ability in designing an advertisement to certain product were still low due to some factors. One of them was the use of conventional material which has nothing to do with the current social lives of the students, for instances the themes that had been used as the example were still discussing about an old brands that the students didn't recognized.

Based on the previous data, the writer tries to answer the research questions; (1) Does social media like Instagram can be developed as the writing material?; 2) Do students' ability in writing using social media can be implemented in e-marketing to design an advertisement?

\section{LITERATURE REVIEW}

The theorical underpinnings of the implementation of social media to develop students' writing in digital marketing had been proposed by (Kannan and Li 2017; Lamberton and Stephen 2016), "online bussiness" in this digital era. They stated that it's a challenging for academic researchers to study more on the important matterof online bussiness.

Businessdictionary.com, 2018 defines digital marketing as a way to promote products or brands through more than one electronic media, for instance advertisement, Internet, social media and electronic billboards, also digital and television and radio channels. There are many ways to stimulate students in developing their ideas in designing ads, one of them by reading the social media like Instagram. The various templates of social media not only the perfect material for writing classes but also a good way to shape the students' business skill.

Advertisement is a notice or announcement in a public medium to promote a product, service, or event or publish a job vacancy (Oxforddictionaries.com, 2019). The use of advertisement can help students to develop their competences. Creating the perfect ads for certain brand can improve not only the language skills of a learner, especially writing skill but also develops the students' confidence in pursuing the digital marketing career. Further, Tsou, Wang and Li, 2002 stated that learners can own many benefits through technology, like electronic media to improve their writing skill; (1) it can develop students 
creativity, analysis, and producing an idea in an easy and effective way in communication, (2) improve collaboration skills between friends and teachers by exchange knowledge via email and sharing files, (3) learners' motivation will build, (4) an effective tool to obtain the human information (Ware and Warschauer as cited in Tsou, 2008). Technology is needed to develop the learning material of all topics.

The material development had been proposed by Tomlinson (2012); a text book, a workbook, a cassette, a CD-ROM, a video, a photocopied handout, a newspaper, a paragraph written on a whiteboard: or anything that can be presented or informed about the languagecalled materials. Further it can be adopted, developed, or adapted, or some combination of the three (Brown, 1995) but the development of the materials should consider approaches and syllabuses. Finally, Yallden (1987) defines syllabus as a "summary of the content to which learners will be exposed".

The learners who have been exposed with the social media as the materials have the different result than they who haven't got the social media text. It proved that the development of teaching material involving not only the syllabus but also the students' need, as Tomlinson (2001: 66) Materials development is both a field of study and a practical undertaking. The development of materials is still need in order to improving students' skills and competences.

\section{RESEARCH METHOD}

The research applied the Research \& development approach ( $R$ \& D) that adopted a model developed by Bough\&Gall, 1983:775, There are ten stages in doing this research, start from research and information gathering to implementation with a combination of qualitative and quantitative researchusing questionnaire using Likert-scale. There are four aspects of questionnaire; appropriateness, language appropriateness, present appropriateness, and layout appropriateness (Badan Standar Nasional Pendidikan).

FurtherSumadinata (2010) stated, if we followed all the stages, it will produce the perfect product.

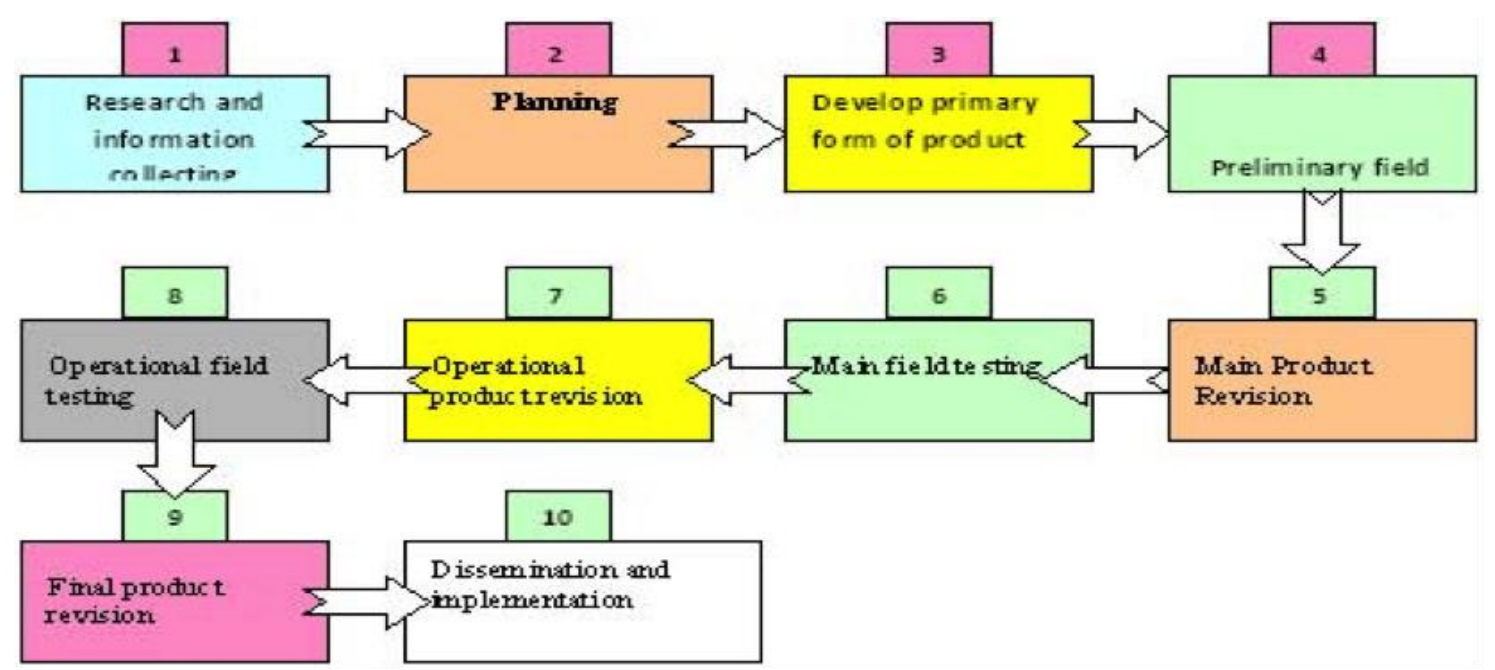

Figure 1: Borg \& Gall, 1983:775.

The population of the research is the second semester English literature program of UNIMED, consist of 30 male and female students with various social, economic and language skills competences. The investigation held for one semestre during the proceess of ESP, reading and writing classes.

The aim of the method is to identify whether social media can be applied as the material in English for Digital Marketing material and students' writing ability using social media can be implemented in e-marketing to design an advertisement. 


\subsection{Designing English for Digital MarketingMaterial}

The first procedure in designing the ESP of digital marketing material was administering the needs analysis. The appropriate English writingmaterial was based on social media like Ig, FB and WA. The writing material was taken from Ig of local or abroad product. Next, as the instruments of the data, the writer selected the material of the assessment limited only to the used of FB, Ig and WA application. Some famous brands that students familiar with like Nike, Brodo or Djoger used as the example of how to design a good and attractive advertisement. Here the example of the text used as the assessment of the students.
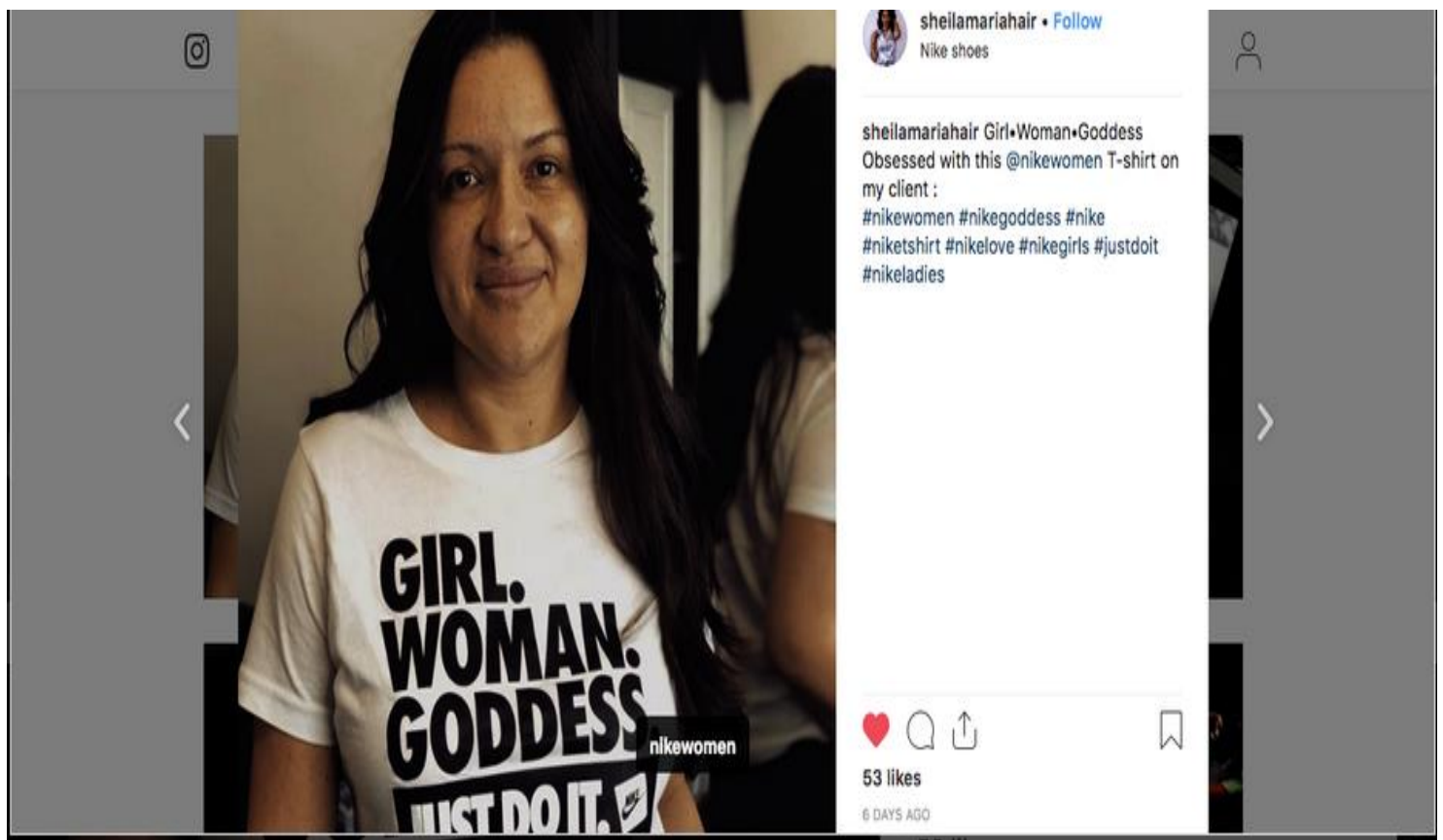

Source:https://www.instagram.com/explore//nike-shoes. Retrieved Jan, 06 ${ }^{\text {th }}$, 2019.

The design of students' advertisements developed into some skills. For reading skills, learners can do the reading aloud activity to understand the message of each brand and makeself correction while reading it. Others member of the group can underline the difficult words in order to compose new idea to be developed in creating new ads. For writing skills, students can choose new diction in group, set the lay out, fit the colour and compose a certain theme adequated with the marketing target of a brand. This assessment's goal is to give a chance to students' creativity to be developed regardless their grammatical competences. It's crucial process as the first step for a beginner to meet they ability in improving their writing skill. The revision had been made after the writer get the result of test lby the experts. Two lecturers who are senior in matter of writing assessment had been point out to make the revision.

\subsection{Validating New Materials by Expert}

The next procedure was evaluation. After the first draft of the materials was developed, the validators evaluated the results tovalidate whether the tests had been appropriate or not. The evaluation consisted of questionnaires and interviews from students and lecturers. The validators demanded to input more brands from local product since Indonesia has many good and famous local brands that had been known around the world.

\subsection{Revising New Materials Based on Experts' Suggestions}

After the first revision, the digital marketing materials had been added more examples of the local brands that the students familiar with and needed to discuss to make a review before they designed their own ads. The purpose of this procedure is to get the appropriate English for Digital Marketing materials to the students need of academic years 2017/2018 who're still beginner learners. They're still learning the simple word with the simple meaning, therefore it's suggested at the end of each topic, the lecturer put the glossary consist of the new terms or difficult words that the students can learn. Next, students were asked to design their own ads for certain brand as their final project.

SALTeL Vol. 2, No. 1, 2019: 18-25 


\subsection{Revised-Developing New Materials (Final Product)}

The writer added somenew developed Digital Marketingmaterials that adequated to the students' need. There were some local brands advertisements as the material of English for Digital Marketing. There were two assessment distributed to the students. The first waspreliminary test that consisted of the advertisement from the hand out and the example was not taken from the social media. Its no relation with the students life and unfamiliar to the students world, an conventional advertisement. The second test wasselected from FB and Ig that related and familiar to the students like the ads of Nike, Djoger, etc. to assess the students' results by implementing the writing score of British Council.

\section{ANALYSIS}

The preliminary data shown that most students want to be part of digital marketing expertise with some reasons;

Table1: The important of digital marketing

\begin{tabular}{|c|c|c|c|c|}
\hline \multirow{4}{*}{$\begin{array}{l}\text { As an English literature students, why do you need to study on line } \\
\text { marketing? }\end{array}$} & $\begin{array}{l}\text { Academic } \\
\text { purposes }\end{array}$ & 30 & 4 & $13 \%$ \\
\hline & Job offer & 30 & 18 & $60 \%$ \\
\hline & Millenial Era & 30 & 7 & $23 \%$ \\
\hline & No purpose & 30 & 1 & $3 \%$ \\
\hline \multirow{4}{*}{ What kinds of digital marketing that you are familiar with? } & tokopedia & 30 & 10 & $33 \%$ \\
\hline & lazada & 30 & 8 & $27 \%$ \\
\hline & bukalapak & 30 & 10 & $33 \%$ \\
\hline & Others & 30 & 2 & $6.7 \%$ \\
\hline \multirow{3}{*}{ Would you consider to be a part of digital marketing expertise? } & Yes & 30 & 22 & $73 \%$ \\
\hline & No & 30 & 7 & $23 \%$ \\
\hline & Hesitate & 30 & 1 & $3 \%$ \\
\hline
\end{tabular}

Its shown that students consider online marketing as one opportunity to get revenue, $60 \%$ of the students believe that by owning online marketing will open an access to be a digital marketing expertise.

Further,the result shown lazada and tokopedia were still the most familiar tenants among students with the average $33 \%$ of users. This investigation made to find out the kind of online marketing that students most frequent accessed and purchased, and to see possibility in designing advertisement to one of both the well known local tenants (tokopedia and lazada).

The next procedure was to find out what kind of application students used as a media to do online marketing. The application only classify into 4 types (Ig, FB, WA and Line). It was made from the previous investigation related to the most common applications used among students. (Natsir \& Suswati, 2018). The following data shown as below;

Table2: The most frequently used as media of digital marketing

\begin{tabular}{|c|c|c|c|c|}
\hline \multirow{4}{*}{ What type of applications mostly used as media ofon line marketing? } & Ig & 30 & 12 & $40 \%$ \\
\hline & FB & 30 & 5 & $17 \%$ \\
\hline & WA & 30 & 8 & $26 \%$ \\
\hline & Line & 30 & 65 & $17 \%$ \\
\hline
\end{tabular}

The data reveilledthat the most familiar application among students to do the digital marketing was Instagram. Almost $40 \%$ of the students choosen Ig as a media to do on line marketing. They purchased many things though social media frequently. The use of social media like Instagram can be implemented into the material of English for Digital Marketing as a way to welcoming the Industrial Revolution 4.0 as President Jowoki initiated. 


\section{RESULT}

The investigation of this study have some result; (1) social media like Instagram can be developed as the writing material,(2) students' ability in writing using social media can be implemented in emarketing to design an advertisement. The preliminary data shown that most students have had familiar with social media and have became part of their lives not only as a way to do the communication but also as a part of their study, their commersial lives of buying and selling anything and other purposes. They also digged the information about their homework from social media. That's why the writer planned to designEnglish material for Digital Marketing using social media as the content.

The results indicates that most students used digital platform all the times, some as a way to join a community, others more smart in using it as a way to get revenue. The students' perception indicated that $60 \%$ of the themthough of digital marketing as a new opportunity and $73 \%$ confirmed that they willbe part of on line marketing expertise.

The rest of the data shown some students have acted as a purchaser, few of them have already being a seller and involved with the customers through social media. Instagram was the most frequent used as a media of digital marketing with $40 \%$ of the students always check new product through Instagram. They most common tenants of digital marketing were bukalapak and tokopedia with the same percentage of $33 \%$.

The validation of the experts recommended that the field work practice (PKL) activity had to consider the digital marketing as the current program of english literature department, since this online marketing had become one of program that had been the launched and initiated by the goverment as a part of the Industrial Revolution 4.0. Surely, it's also prosperous carreer for the learners.

\section{CONCLUSION}

The conclusion of the investigation The Implementation of Social Media To Develop Students' Writing Skill On Digital Marketing, it is assumed that social media can be implemented as the material of English for Digital Marketing. Social media like Instagram, FB and WA can be taken as a source of writing class in designing an advertisement to certain brand as part of digital marketing expertise.

According to Indonesia President, Jokowi; digital marketing is a way to anticipating the marketing industry around the worls. The old term KKN (Corruption, Collution and Nepotism) should revised into new term(Communication, Collaboration and Networking) to reform the Indonesia Marketing. The purposes of digital world should expanded from the amusement purposes into the revenue purposes. Further investigation will be needed to get the complete data on the implementation of digital marketing for educational purposes or other interests.

\section{REFERENCES}

Arnold, M.J. and Reynolds, K.E. (2003), "Hedonic shopping motivations”, Journal of Retailing, 79 (2) 77-95. Avlonitis,

Anniek W. Eigenraam \& Jiska Eelen\& Arjen van Lin\& Peeter W.J. Verlegh A Consumer-based Taxonomy of Digital Customer Engagement Practices 论 Department ofMarketing, Vrije Universiteit Amsterdam, De Boelelaan 1105, 1081 HVAmsterdam.

Alvarez, Claudio and Susan Fournier (2016), "Consumers' Relationships with Brands," Current Opinion in Psychology, 10, 129-35.

Brown, J., D. The Elements of Language Curriculum. Boston: Heinle\&Heinle Publishers, 1995.

Kannan, P.K. and Hongshuang Alice Li (2017), "Digital Marketing: A Framework, Review and Research Agenda," International Journal of Research in Marketing, 34, 1, 22-45.

King, G., and Sen, M. (2013) The Teacher: How Social Science Research Can Improve Teaching American Political Science Association, PS: Political Science and Politics 46 (3), 621-629. 
Tsou, W. (2008). The effect of a web-based writing program in collegeEnglish writing classes. IEEE Computer Society Washington, DC, USA.Retrieved on October 25, 2017from: http://portal.acm.org/citation.cfm?id=1381740.

Tsou, W; Wang, W., \& Li, H. (2002). How computers facilitate English foreign language learners acquire English words. Computers \& Education, 39(4), 415-428.

Tomlinson, B. (2012). Materials Development in Language Teaching. United Kingdom: Cambridge

Yalden, J. The Communicative Syllabus: Evolution, Design and Implementation. Englewood Cliffs N.J.: Prentice Hall International, 1987.

Yacoba, Kadirb, Zainudinc, Zurairah (2011). Student Awareness Towards E-Learning In Education.Elsevier Ltd.International Conference on e-Learning, ICEL 2011 Bandung, Indonesia.

Ware, P., \&Warschauer, M. (2005).Hybrid literacy text and practices in technology intensive environments International Journal of Educational Research, 43, 415-448

Zepke, N., and Leach, L. (2010) Improving student engagement: Ten Proposals for action. Active Learning In Higher Education.11, 167-177

CNN Indonesia.com. retrieved Dec 08, 2018 from CNN Indonesia.com website: https://www.cnnindonesia.com/gaya-hidup//metode-pendidikan

http://www.businessdictionary.com/definition/digital-marketing.html. retrieved Dec, 09th, 2018.

https://en.oxforddictionaries.com/definition/advertisement. retrieved, Jan 05th, 2019

https://www.instagram.com/explore/ /nike-shoes.retrieved Jan 06 ${ }^{\text {th }}, 2019$. 